Anais da Academia Brasileira de Ciências (2005) 77(1): 137-155

(Annals of the Brazilian Academy of Sciences)

ISSN 0001-3765

www.scielo.br/aabc

\title{
C- and Sr-isotope stratigraphy of the São Caetano complex, Northeastern Brazil: a contribution to the study of the Meso-Neoproterozoic seawater geochemistry
}

\author{
JUAN C. SILVA ${ }^{1}$, ALCIDES N. SIAL ${ }^{1}$, VALDEREZ P. FERREIRA ${ }^{1}$ and MÁRCIO M. PIMENTEL ${ }^{2}$ \\ ${ }^{1}$ NEG-LABISE, Departamento de Geologia, Universidade Federal de Pernambuco \\ Cx. Postal 7852 - 50670-000 Recife, PE, Brasil \\ ${ }^{2}$ Instituto de Geociências, Universidade de Brasília, Centro Universitário, ASA Norte \\ 70910-900 Brasília, DF, Brasil
}

Manuscript received on January 26, 2004; accepted for publication on June 14, 2004; contributed by Alcides N. Sial*, Valderez P. Ferreira* and Márcio M. Pimentel*

\begin{abstract}
C-isotope and ${ }^{87} \mathrm{Sr} /{ }^{86} \mathrm{Sr}$ values for five carbonate successions from the São Caetano Complex, northeastern Brazil, were used to constrain their depositional age and to determine large variations in the C- and $\mathrm{Sr}$ isotopic composition of seawater under the framework of global tectonic events. Three $\mathrm{C}$-isotope stages were identified from base to top in a composed chemostratigraphic section: (1) stage in which $\delta^{13} \mathrm{C}$ values vary from +2 to $+3.7 \%$ PDB and average $3 \% \circ \mathrm{PDB}$, (2) stage with $\delta^{13} \mathrm{C}$ values displaying stronger oscillations (from $-2 \%$ to $+3 \%$ PDB), and (3) stage with an isotopic plateau with values around $+3.7 \%$ PDB. Constant ${ }^{87} \mathrm{Sr} /{ }^{86} \mathrm{Sr}$ values $(\sim 0.70600)$ characterize $\mathrm{C}$-isotope stage 1 , whereas slightly fluctuating values (from 0.70600 to 0.70700 ) characterize $\mathrm{C}$-isotope stage 2 . Finally, ${ }^{87} \mathrm{Sr} /{ }^{86} \mathrm{Sr}$ values averaging 0.70600 characterize C-isotope stage 3.

The C-and Sr- chemostratigraphic pathways permit to state: (a) the C-and $\mathrm{Sr}$-isotope secular curves registered primary fluctuations of the isotope composition of seawater during late Mesoproterozoic- early Neoproterozoic transition in the Borborema Province, and (b) onset of the Cariris Velhos/Greenville cycle, widespread oceanic rifting, continental magmatic arc formation and onset of the agglutination of Rodinia supercontinent, mostly controlled the C- and Sr-isotope composition of seawater during the C-isotope stages 1, 2 and 3.
\end{abstract}

Key words: C-isotopes, Meso-Neoproterozoic, chemostratigraphy, Borborema Province, Northeastern Brazil.

\section{INTRODUCTION}

Well-constrained C- and Sr-isotope chemostratigraphic data for Proterozoic limestone sequences have been used to detect changes in the geochemical

*Member Academia Brasileira de Ciências Correspondence to: Juan C. Silva

Present address:Department of Earth and Planetary Sciences, 306 Geological Sciences Building, University of Tennessee Knoxville, TN 37996-1410, USA

E-mail: jsilva1@utk.edu composition of ancient seawater and their possible causes (Jacobsen and Kaufman 1999, Bartley et al. 2001, Lindsay and Brasier 2002). Changes in the C- and Sr-composition of the Proterozoic seawater result from the net interaction of several endogenic and exogenic mechanisms, among which tectonic activity, biologic radiations and amazing climatic changes are of remarkable importance (Melezhik et al. 1997, Brasier and Lindsay 1998, Hoffman and 
Schrag 2002, Bekker et al. 2003).

The Mesoproterozoic - early Neoproterozoic chemostratigraphic record has been a topic of continuous discrepancies among geologists given that the lack of well-preserved stratigraphic sections has not permitted the achievement of a well-constrained geochemical database. Few works (e.g Knoll et al. 1995, Hall and Veizer 1996, Frank et al. 1997, 2003, Kah et al. 1999, 2001, Santos et al. 2000, Bartley et al. 2001, Azmy et al. 2001, Maheshwari et al. 2002, Bartley and Kah 2003) have supplied reliable chemostratigraphic information for the construction of well constrained C- and Sr-isotope secular variation curves. Therefore, establishing factors that affected the seawater geochemistry during this time span has remained difficult. Based on the available data, it has been proposed that the early Mesoproterozoic C- and $\mathrm{Sr}$ - isotope composition of seawater remained in an apparent long-lasting steady state (Buick et al. 1995, Brasier and Lindsay 1998), while the middle-late Mesoproterozoic- early Neoproterozoic composition of seawater seems to have registered stronger perturbations in the geochemical cycles as a result of miscellaneous factors (Brasier and Lindsay 1998, Kah et al. 1999, Bartley et al. 2000, 2001, Bartley and Kah 2003, Frank et al. 1997, 2003).

The São Caetano Complex (SCC) marble sequences, located in the Transversal Domain of the Borborema Structural Province (BSP), northeastern Brazil (Fig. 1), is a good candidate to unravel the above mentioned chemostratigraphic problems, although its sedimentation and metamorphism ages have been poorly constrained. This work aims at: (1) indirectly constrain the depositional age of the SCC, by comparing its $\mathrm{C}$ and Sr-isotope chemostratigraphic curves with previously calibrated ones from other sequences worldwide, (2) enhance the global C- and Sr- isotope stratigraphy database for the late Mesoproterozoic- early Neoproterozoic time span and (3) contribute to explain on how major tectonic events produced main $\mathrm{C}$ - and $\mathrm{Sr}$ - isotope perturbations in the ocean water geochemistry during this period of the Earth's history. Finally, since our isotopic database published in this work was obtained from marble sequences (amphibolite facies), it is also aimed to assess how metamorphism may have affected the original $\mathrm{C}$ - and $\mathrm{Sr}$ - isotope composition of SCC carbonate sequences.

\section{GEOLOGIC SETTING AND AGE}

The São Caetano Complex (SCC) is located in the Alto Pageú Terrane (APT), Transversal Domain of the Borborema structural province (BSP), northeastern Brazil (Fig. 1). It is a metavolcano-sedimentary sequence characterized by garnet-biotite paragneiss, quartzite, marble, metapelite, metagraywacke, metadacite, metarhyolite, and metabasalt, metamorphosed in the amphibolite-facies during late Neoproterozoic (0.75-0.5 Ga.; Brito Neves et al. 2000).

This complex is associated to metavolcanic sequences and MORB mafic-ultramafic suites (e.g. Riacho-Gravata belt and Serrote das Pedras Pretas complex), which are interpreted as part of a midoceanic rift sequence developed at $\sim 1.05 \mathrm{Ga}$ (Van Schmus et al. 1995), and intruded by early and middle Neoproterozoic plutons (Brito Neves et al. 2000 and references therein). The SCC is also associated to some marine Neoproterozoic metasedimentary sequences (Cachoeirinha Complex), but field relationships between them are not conclusive.

No agreement on the stratigraphic position of the SCC has been reached thus far. The lack of high-resolution stratigraphic information has made its temporal characterization difficult, leading to several stratigraphic proposals. Despite the SCC has been strongly affected by regional shear zones and has been extensively intruded by Neoproterozoic plutonic suites during the Cariris Velhos cycle (0.96-0.95 Ga; Kozuch unpublished data), and Pan-African/Brasiliano orogeny (Brito Neves et al. 2000), the marble successions studied here have thicknesses and extensions that can assure their regional character.

The studied SCC marble successions are mainly calcitic and contain silicate mineral assem- 


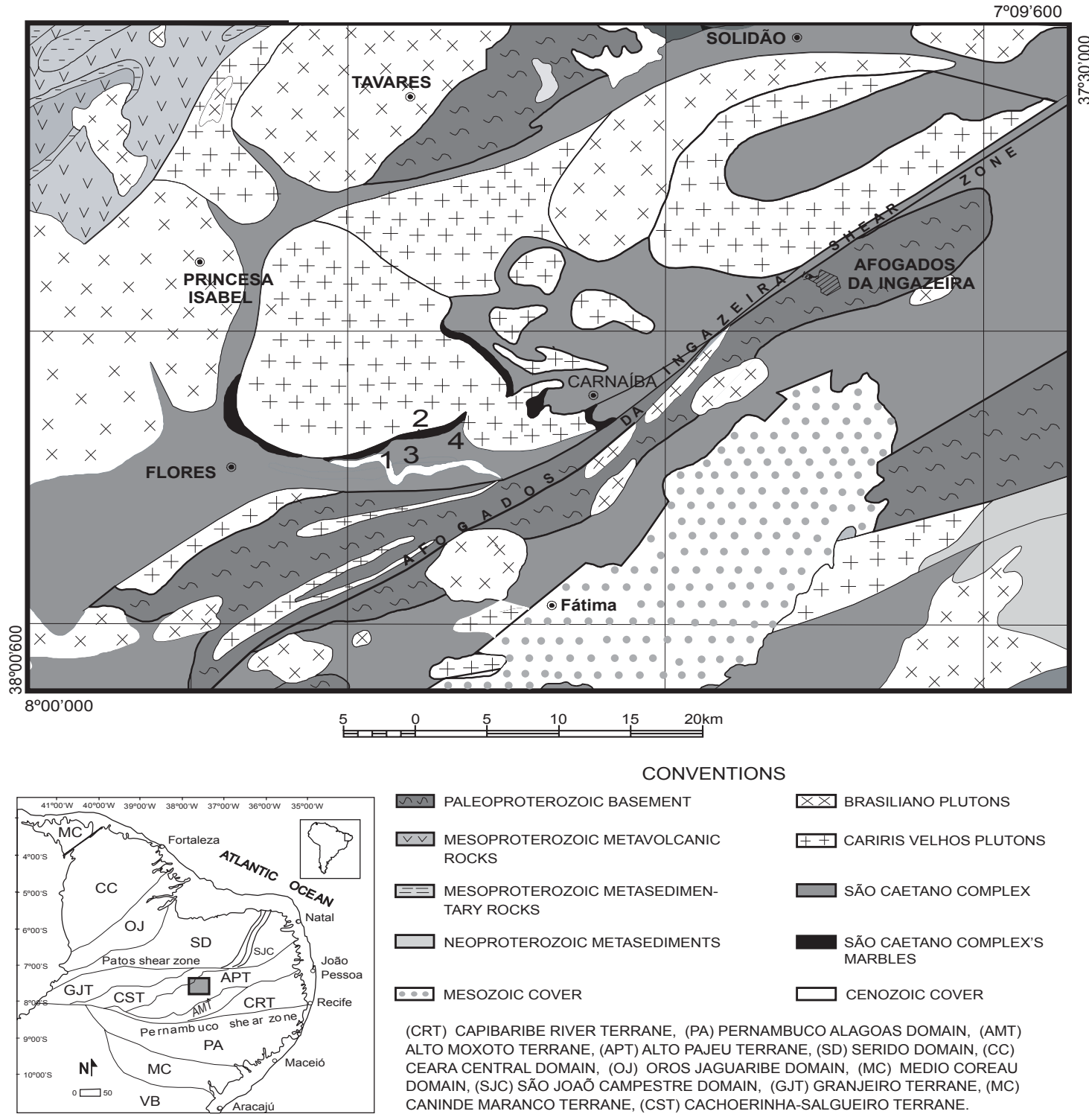

Fig. 1 - Geologic map of the studied area. Numbers represent the location of the stratigraphic sections: 1. Pedra de Cal, 2. Santa Rosa, 3. Malutagem, 4. Rodiador. Tectonic terranes map are from Ferreira et al. (1998). Geologic map modified from Gomes (1999).

blages typical of amphibolite facies (diopsidetremolite-muscovite-garnet). These marbles contain considerable amounts of graphite, which are disposed in layers and present different cyclic pathways (Fig. 2). They are interbedded with siliciclastic successions, and their thickness diminishes upward section. In spite of strong folding and shearing to which the SCC has undergone, the marble sequences seem to have preserved original stratigrafic polarity. This is corroborated by the presence of non-mimetic chemostratigraphic pathways as discussed below.

The age of the SCC is poorly constrained. The oldest age ( $>1.3 \mathrm{Ga}$.) ascribed to this complex was inferred from sedimentary zircons of Archean to Late Mesoproterozoic collected from siliciclastic successions in the uppermost portion of the SCC 

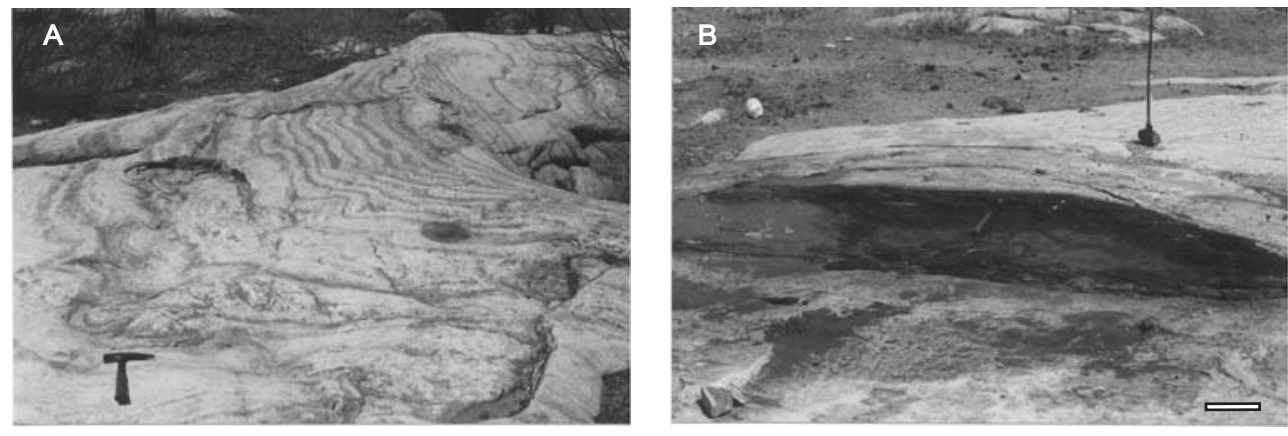

Fig. 2 -A. Marble succession presenting cyclic graphite-rich layers (Pedra de Cal section). B. Amphibolite layer interlayered with marbles in the Pedra de Cal Section. The white rectangle is $40 \mathrm{~cm}$ long.

(Brito Neves et al. unpublished data). The youngest age for this complex was assumed from a $0.96 \mathrm{Ga}$ $(\mathrm{U}-\mathrm{Pb})$ age determined for a granodioritic-biotite orthogneiss that intruded the siliciclastic successions overlying the studied marbles (Kozuch unpublished data).

\section{MATERIALS AND METHODS}

Marble samples were thin-sectioned in order to determine their petrographic characteristics and to evaluate whether silicate phases or graphite had some effect on the isotopic record. Determinations of minor and major elements were performed using X-Ray fluorescence to support the petrographic analyses and to further evaluate post-depositional alterations. These analyses were performed in a Rigaku RIX 3000 XRF unit, equipped with an Rh tube, at the XRF laboratory, Department of Geology, Federal University of Pernambuco. Analyses of major and minor elements are reported in parts per million (ppm).

For C- and O-isotope analyses, powdered carbonate samples were reacted with $100 \%$ orthophosphoric acid during 12 hours at $25^{\circ} \mathrm{C}$. The $\mathrm{CO}_{2}$ released from this reaction was extracted in a highvacuum extraction line by using cryogenic cleaning according to the method proposed by Craig (1957). The $\mathrm{CO}_{2}$ samples were analyzed for $\mathrm{C}$ and $\mathrm{O}$ - isotopes in a multi-collector double-inlet gas source mass spectrometer (Sira II), at the Stable Isotope
Laboratory (LABISE), Department of Geology, Federal University of Pernambuco. The isotopic composition were contrasted against the in-house standard Borborema Skarn Calcite (BSC), which calibrated against the NBS-18, NBS-19 and NBS20 standards, shows an isotopic composition of $\delta^{18} \mathrm{O}=-1.28 \pm 0.04 \%$ PDB and $\delta^{13} \mathrm{C}=-8.58 \pm$ $0.02 \%$ PDB. Results are reported in the international $\delta \%$ (delta permil) notation respect to the PDB scale.

For determination of the Sr-isotopic composition, $5 \mathrm{mg}$ of powdered carbonate sample were dissolved in $0.5 \mathrm{M}$ ultraclean acetic acid for leaching, and centrifuged to obtain purified $\mathrm{Sr}$. $\mathrm{Rb}$ and $\mathrm{Sr}$ were separated from the leached solutions by standard ion-exchange techniques. Following, 500 to $1000 \mathrm{ng}$ of purified $\mathrm{Sr}$ were loaded onto Ta filament, along with $1 \mu \mathrm{m} \mathrm{H}_{3} \mathrm{PO}_{4}$, for TIMS analysis, in a seven collector Mat 262 instrument at the Geochronology Laboratory, Institute of Geosciences, University of Brasilia.

\section{CONSTRAINING POST-DEPOSITIONAL ISOTOPIC ALTERATION}

C- and Sr-isotope composition of marine carbonate materials has been successfully used to determine changes in the geochemistry of ancient oceans (Veizer and Hoefs 1976). Nevertheless, diagenesis and/or metamorphism have been considered as potential processes capable to cause post-depositional 
alteration of the original C- and Sr-isotope signatures. When submitted to either one of these processes, carbonates undergo textural, mineralogical and geochemical alterations; favored by (1) presence of C-and/or Sr- bearing minerals, (2) presence of intergranular or intercrystalline fluids, whose Cand Sr-isotope compositions differ from that of the carbonate, (3) abundance of primary elements into the carbonate lattice, and (4) extent of the waterrock interaction during precipitation, deposition and post-depositional processes (Brand and Veizer 1980a,b, Banner and Hanson 1990, Kaufman et al. 1991).

The presence of silicate minerals and/or graphite has been considered as a potential factor capable of generating post-depositional change of the original $\mathrm{C}$-isotope signature of carbonates, leading to depletions of their $\delta^{13} \mathrm{C}$ values (Shieh and Taylor 1969). It has been also determined that the presence of silicate minerals affect the original $\delta^{18} \mathrm{O}$ and ${ }^{87} \mathrm{Sr} /{ }^{86} \mathrm{Sr}$ signatures as well (Chacko et al. 1991, Valley and O'Neil 1981, Valley 2001). Additionally, it has been established that paired depletions in $\delta^{18} \mathrm{O}$ and $\delta{ }^{13} \mathrm{C}$ chemostratigraphic trends can be expected during post-depositional isotopic alteration.

In order to determine post-depositional alteration and discriminate altered samples, which can yield erratic chemostratigraphic pathways, a petrographic characterization of the carbonates samples was performed. In general, studied marbles present coarse-grained calcite ( 0.8 to $4 \mathrm{~mm}$ ). Graphite contents vary between 0 and $8 \%$ and present a general coarsening up tendency (grain sizes from 0.1 to $2 \mathrm{~mm}$ ). It is either randomly disposed in layers or in disseminated form. Silicate phases (quartz, muscovite, tremolite, and diopside) are no representative (Fig. 3). No dissolution or exsolution textures were found, except when calcite crystals are in contact with graphite.

Given to the presence of graphite and silicate minerals in the SCC marbles, $\delta^{18} \mathrm{O}, \delta^{13} \mathrm{C}$ and ${ }^{87} \mathrm{Sr} /{ }^{86} \mathrm{Sr}$ data were cross-plotted and examined against some other geochemical tracers to determine possible post-depositional modifications (Fig. 4).
Besides, the $\delta^{13} \mathrm{C}$ and $\delta^{18} \mathrm{O}$ secular variation curves were contrasted against the presence of graphite and silicate minerals (Figs. 5, 6). No paired depletions were identified and no relationship was found between presence of silicate minerals and anomalously depleted isotopic values (Fig. 6). Depletions in the $\delta{ }^{13} \mathrm{C}$ occur independently of the presence and variations in the percentage of silicate minerals and an opposite behavior was observed when comparing the $\delta^{13} \mathrm{C}$ curve with the graphite content one. In general depletions on the $\delta^{13} \mathrm{C}$ values accompany increases in graphite content and size, in sectors where the graphite occurs accumulated in layers (Figs. 5, 6).

Other geochemical parameters were used to further investigate post-depositional alterations, following methods proposed by Derry et al. (1992), Kaufman et al. (1991, 1993) and Kaufman and Knoll (1995) (Table I, Fig. 4). Sr contents varying from 552 to $2487 \mathrm{ppm}$ and averaging $1500 \mathrm{ppm}$, as well as $\mathrm{Mn} / \mathrm{Sr}$ ratios varying from 0.006 to 0.140 , and $\mathrm{Rb} / \mathrm{Sr}$ ratios between 0 and 0.005 , were found in the SCC marbles. These values perfectly meet the unaltered ratio ranges proposed by Bartley et al. (2001) for unaltered limestone sequences in Siberia, and are in close agreement with those lying in the field of unaltered samples ( $\mathrm{Sr}$ contents $>1000 \mathrm{ppm}$ ) proposed by Brand and Veizer (1980a). Additionally, most of the obtained $\mathrm{Sr}$ values fall within the unaltered range (1100 and $1400 \mathrm{ppm}$ ) that Kah et al. $(1999,2001)$ proposed as representative of pristine seawater composition in Meso-Neoproterozoic limestone sequences located in Canada.

In summary, the elemental composition of most of the analyzed SCC marble samples lies in the fields of unaltered rocks (Fig. 4). This indicates that the original composition of the limestone sequences has been preserved and effectively buffered during early diagenesis by ocean diagenetic fluids, preventing post-depositional alteration and allowing to low water-rock interaction (W-R) during diagenesis and metamorphism. However, few postdepositional modifications of the $\mathrm{C}$-isotope record were found for samples with high graphite content. Carbonate samples with anomalously negative 

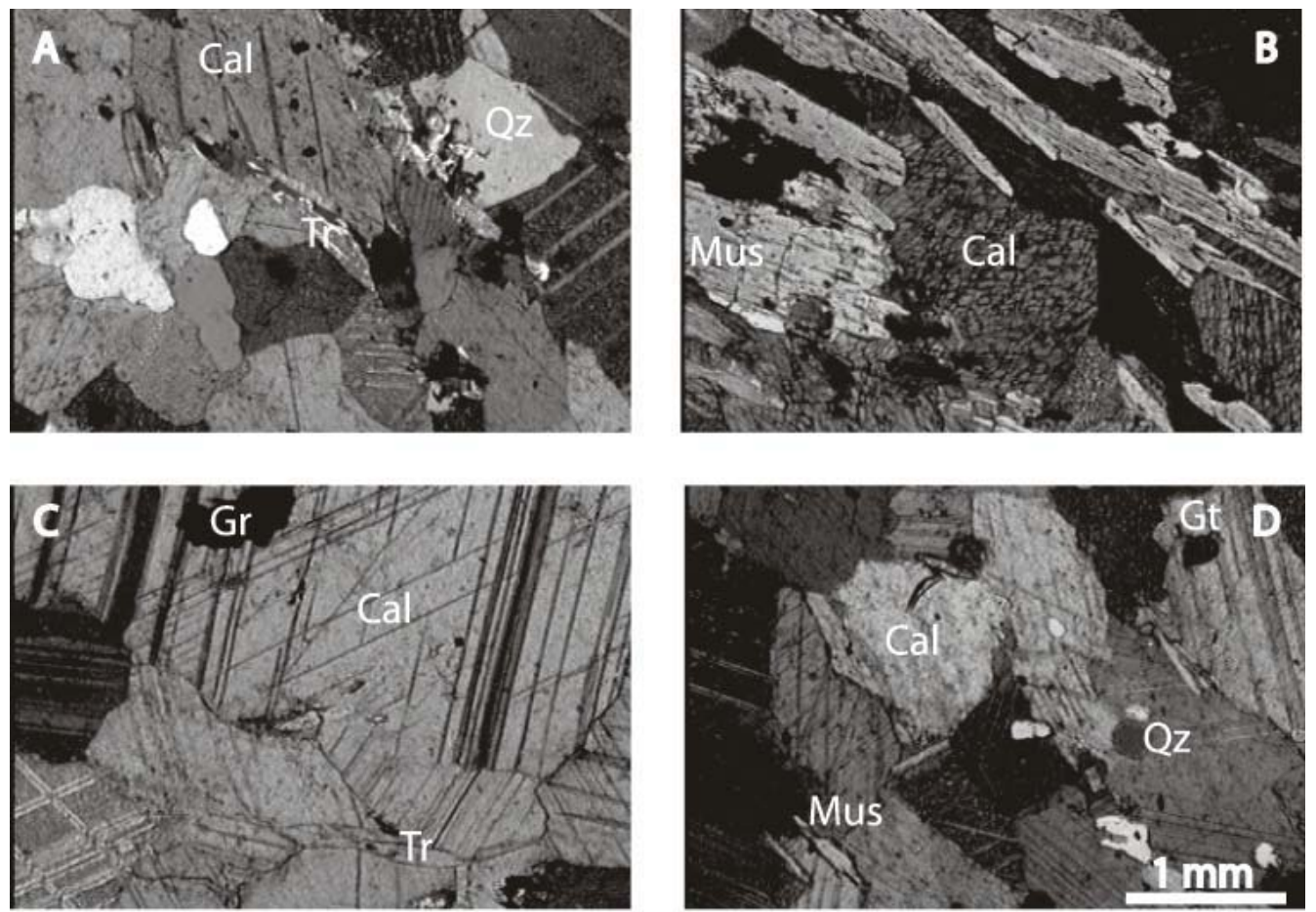

Fig. 3 - Main petrographic characteristics of the SCC marbles. Thin sections from the Pedra de Cal (A), Malutagem (B), Rodiador (C) and Santa Rosa (D) sections. Calcite (Ca), quartz (Qz), tremolite (Tr), garnet (Gt), graphite (Gr), muscovite (Mus).

$\delta^{13} \mathrm{C}$ are thought to be a result of possible post-depositional alteration due to graphite derived $\mathrm{CO}_{2} / \mathrm{CH}_{4}$ - calcite fractionation during diffusion. These processes, which have been reported by several authors (e.g. Dunn and Valley 1992, Kitchen and Valley 1995, Satish-Kumar et al. 2002), would have not effectively altered the whole marble sequence due to the low W-R interaction proposed above. Nonetheless, more analyses and evaluation are needed to further constrain this process.

\section{CHEMOSTRATIGRAPHY}

\section{C-ISOTOPE Chemostratigraphy}

About 120 samples from five continuous marble stratigraphic sections near Flores Town (Pedra de Cal, Santa Rosa, Rodiador, Malutagem localities) and near Sitio dos Nunes town, Pernambuco, were analyzed for C- and O- isotopes (Fig. 1).
The thicker and most complete stratigraphic section (Pedra de Cal locality) consists of 44 samples that correspond to nearly $110 \mathrm{~m}$ of continuous profile (Fig. 5a). The sequence starts with a very oscillating $\delta^{13} \mathrm{C}$ pathway, which fluctuates between $+2 \%$ pDB and $+3.6 \%$ PDB and presents some depletion to values around $1 \%$ PDB. Upsection, those values remain almost constant, averaging $+2.3 \% \mathrm{PDB}$, then decrease to values as low as $-2.2 \%$ PDB and finally stabilize around $-1.5 \%$ PDB. Some positive shifts (of no more than $0.5 \%$ PDB) are also noticeable. A positive excursion, from 0 to $+1.8 \%$ PDB, characterizes the upper portion of the section just before falling to values around 0 and $-1 \%$ PDB in its uppermost portion.

The Malutagem (Fig. 5b) and Sitio dos Nunes sections (Fig. 5c) display predominantly negative $\delta^{13} \mathrm{C}$ values. Both sections start with oscillating values, in which shifts from $-2.6 \%$ PDB to 
TABLE I

Geochemical analyses of representative samples of the studied marble sequences.

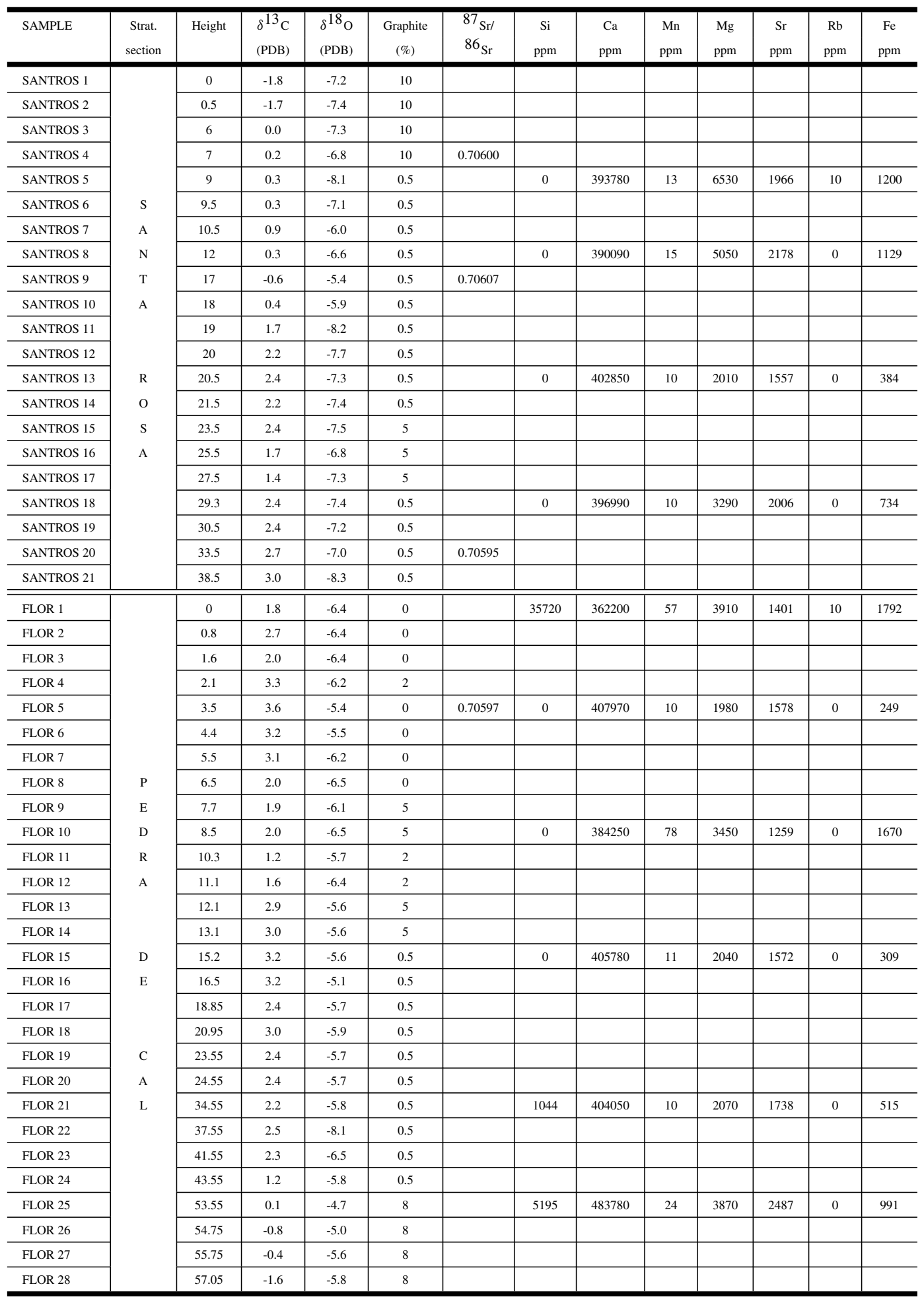


TABLE I (continuation)

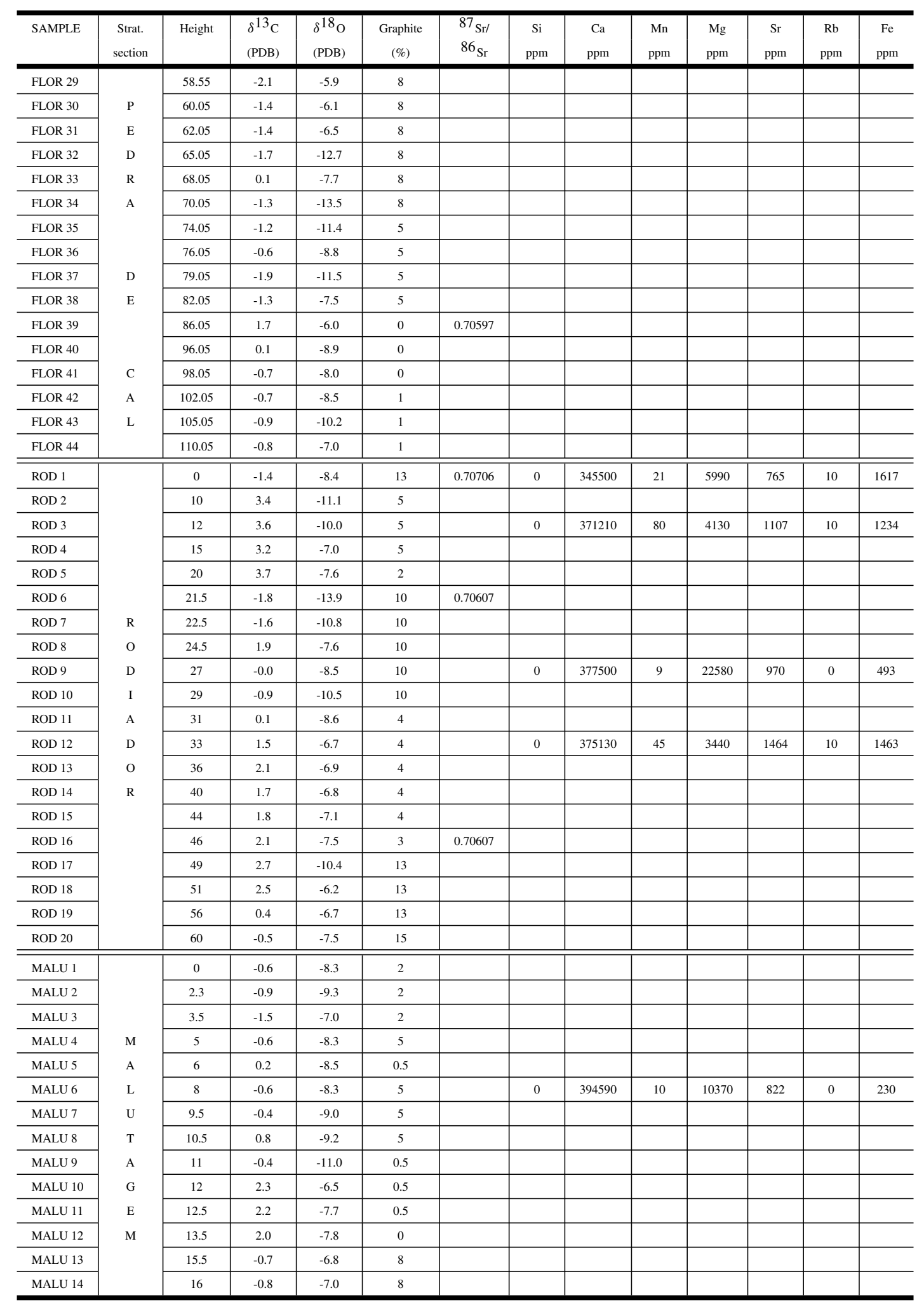


TABLE I (continuation)

\begin{tabular}{|c|c|c|c|c|c|c|c|c|c|c|c|c|c|}
\hline SAMPLE & $\begin{array}{l}\text { Strat. } \\
\text { section }\end{array}$ & Height & $\begin{array}{l}\delta^{13} \mathrm{C} \\
\text { (PDB) }\end{array}$ & $\begin{array}{l}\delta^{18} \mathrm{O} \\
\text { (PDB) }\end{array}$ & $\begin{array}{c}\text { Graphite } \\
(\%)\end{array}$ & $\begin{array}{l}{ }^{87} \mathrm{Sr} / \\
{ }^{86} 6_{\mathrm{Sr}}\end{array}$ & $\begin{array}{c}\mathrm{Si} \\
\mathrm{ppm}\end{array}$ & $\begin{array}{c}\mathrm{Ca} \\
\mathrm{ppm}\end{array}$ & $\begin{array}{l}\text { Mn } \\
\text { ppm }\end{array}$ & $\begin{array}{l}\mathrm{Mg} \\
\mathrm{ppm}\end{array}$ & $\begin{array}{c}\mathrm{Sr} \\
\mathrm{ppm}\end{array}$ & $\begin{array}{l}\mathrm{Rb} \\
\mathrm{ppm}\end{array}$ & $\begin{array}{l}\mathrm{Fe} \\
\mathrm{ppm}\end{array}$ \\
\hline MALU 15 & M & 16.5 & -0.3 & -6.9 & 8 & & 0 & 400610 & 29 & 2900 & 2142 & 0 & 382 \\
\hline MALU 16 & A & 19.5 & 0.2 & -7.4 & 8 & & & & & & & & \\
\hline MALU 17 & L & 20.5 & 0.2 & -7.6 & 9 & & & & & & & & \\
\hline MALU 18 & U & 21.5 & -0.5 & -7.5 & 5 & & & & & & & & \\
\hline MALU 19 & $\mathrm{~T}$ & 24.5 & -0.8 & -8.1 & 5 & & & & & & & & \\
\hline MALU 20 & A & 25 & -1.7 & -13.9 & 5 & & & & & & & & \\
\hline MALU 21 & G & 26 & -1.7 & -13.9 & 5 & & 0 & 366180 & 65 & 4000 & 2014 & 10 & 5164 \\
\hline MALU 22 & E & 27 & -1.1 & -13.8 & 5 & & & & & & & & \\
\hline MALU 23 & M & 28 & -0.8 & -9.7 & 5 & & & & & & & & \\
\hline NUNES 1 & \multirow{6}{*}{ SITIO } & 0 & -2.6 & -7.5 & 10 & & 0 & 349890 & 79 & 6350 & 1658 & 22 & 2201 \\
\hline NUNES 2 & & 1.2 & -2.2 & -6.0 & 10 & 0.70681 & & & & & & & \\
\hline NUNES 3 & & 2.2 & -2.3 & -6.5 & 8 & & & & & & & & \\
\hline NUNES 4 & & 4.2 & -1.4 & -9.7 & 8 & & & & & & & & \\
\hline NUNES 5 & & 5.7 & -2.1 & -6.8 & 8 & & & & & & & & \\
\hline NUNES 6 & & 9.2 & -2.2 & -6.1 & 8 & & 0 & 379950 & 51 & 10490 & 552 & 10 & 1757 \\
\hline NUNES 7 & \multirow[t]{4}{*}{ NUNES } & 11.2 & 2.3 & -7.5 & 0.5 & & & & & & & & \\
\hline NUNES 8 & & 12.7 & -1.1 & -6.6 & 8 & 0.70594 & 0 & 363310 & 38 & 3930 & 1968 & 0 & 5520 \\
\hline NUNES 9 & & 14.7 & -2.1 & -8.5 & 8 & 0.70696 & 0 & 382460 & 81 & 6330 & 574 & 10 & 1939 \\
\hline NUNES 10 & & 15.7 & -0.9 & -8.9 & 8 & & & & & & & & \\
\hline
\end{tabular}

$\sim+1 \%$ PDB are identified. This pathway is interrupted by a very pronounced enrichment from -1.5 to $+2.5 \%$ PDB, which finally decreases to values near $-2 \%$ PDB upsection.

The Santa Rosa (Fig. 5d) and Rodiador (Fig. 5e) sections display the most positive $\delta^{13} \mathrm{C}$ values in this study. Both sections start with negative $\delta^{13} \mathrm{C}$ values, $-1.8 \%$ PDB and $-1.4 \%$ PDB respectively, which then increase upsection reaching values as high as $+3.7 \%$ РDB. In the Rodiador section those positive values sporadically decrease to values near $-1.8 \% \mathrm{PDB}$, which were interpreted as the result of post-depositional alteration; whereas in the Santa Rosa section, positive values $(+2.7 \%$ PDB $)$ are preserved and no shift towards negative values has been recorded.

Samples with possible post-depositional alteration were discarded (see previous section) and the $\delta^{13} \mathrm{C}$ chemostratigraphic pathways were used to correlate the stratigraphic sections and to construct a composite $\mathrm{C}$-isotope variation curve (Fig. 6). The correlation between stratigraphic sections was performed contrasting $\mathrm{C}$-isotope anomalies. Three Cisotope stages were identified: (a) $\mathrm{C}$-isotope stage
1 , mostly characterized by the presence of positive $\delta^{13} \mathrm{C}$ values (from +2.3 to $+3.6 \%$ PDB ); (b) $\mathrm{C}$ isotope stage 2 , characterized by a very fluctuating $\delta^{13} \mathrm{C}$ pathway, which starts with a large negative excursion (from $\sim+2$ to $\sim-2 \%$ PDB), then increase to values $\sim+2.4 \%$ PDB , to subsequently shift back to values near $-2 \%$ PDB and to finally increase towards values around $3 \% \mathrm{PDB}$; and (c) C-isotope stage 3 that displays a noticeable and constant increase, from $\sim-2 \%$ PDB to $\sim+3.7 \%$ PDB.

The composite chemostratigraphic trends are accompanied by changes in the chemical and mineralogical composition of carbonates. An increasing, upward tendency in the $\mathrm{Mg} / \mathrm{Ca}$ ratio, accompanied by the presence of few silicate phases (predominantly quartz, muscovite and tremolite) and variable amounts of graphite, characterizes the $\mathrm{C}$ isotope stage 1 . On the other hand, low graphite contents and slightly higher amounts of silicate minerals (quartz and tremolite) characterize C-isotope stage 2 , in which a mimetic behavior between the $\mathrm{Mg} / \mathrm{Ca}$ ratios and the $\mathrm{C}$-isotope values is observed. Finally, C-isotope stage 3 contains low amounts of graphite and silicate minerals and presents an in- 


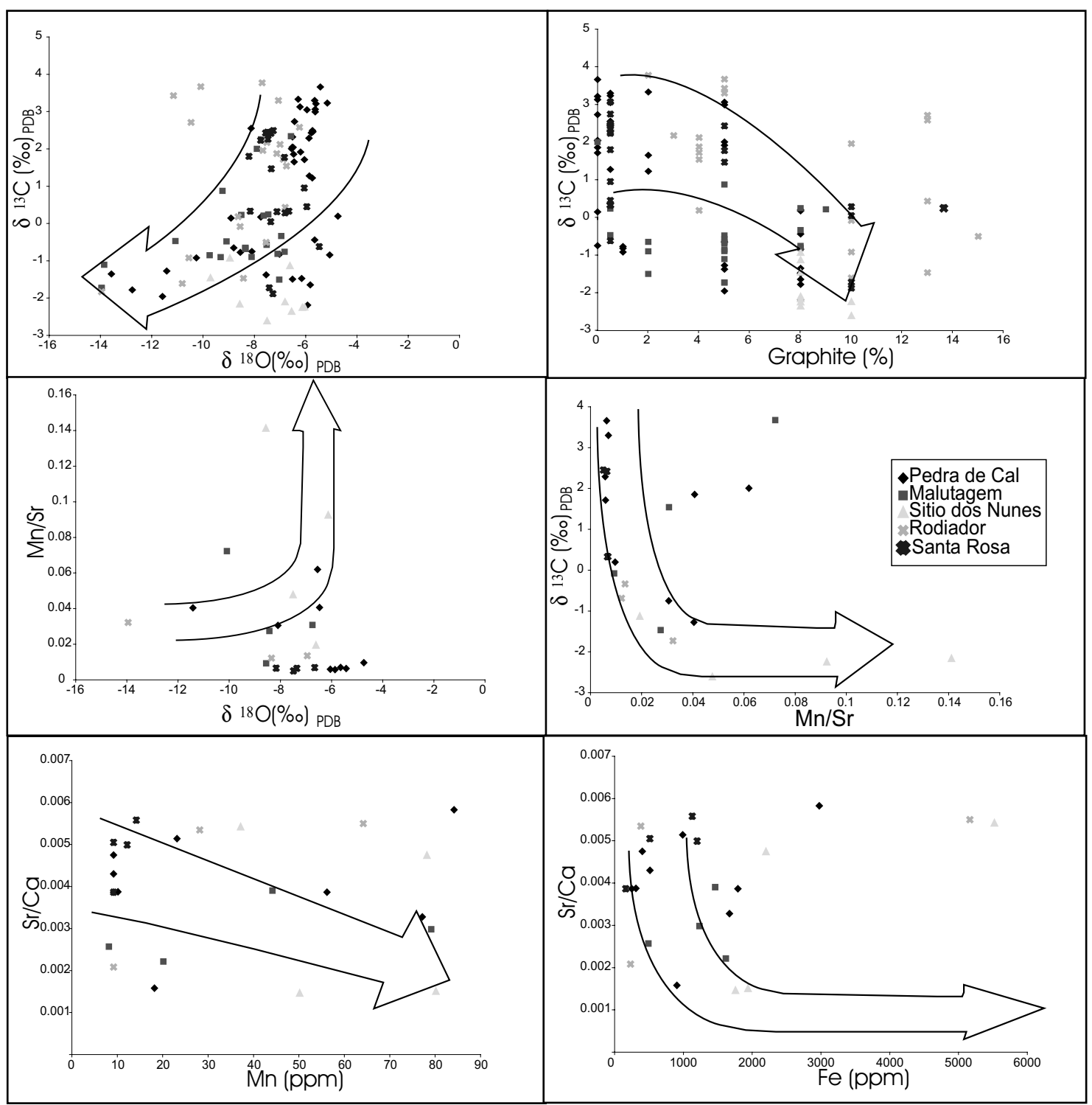

Fig. 4-Cross-plots of isotopic and elemental data from all studied stratigraphic sections. Arrows indicate geochemical postdepositional alteration trends, showing that most samples fall in the unaltered fields. Geochemical trends were used as proposed by Derry et al. (1992), Kaufman et al. (1991, 1993) and Kaufman and Knoll (1995).

creasing tendency in the $\mathrm{Mg} / \mathrm{Ca}$ ratios, which is less pronounced in magnitude that those observed in Cisotope stage 2 (Fig. 6).

In summary, changes in $\mathrm{C}$-isotope chemostratigraphic trends keep a co-variation with $\mathrm{Mg} / \mathrm{Ca}$ ratios and amount of graphite (Fig. 6). As exposed above, shifts in the $\mathrm{C}$-isotope composition of carbonates coincide with changes in the amount of graphite (Figs. 4, 5) and its distribution in outcrop (Fig. 2). Low amounts of graphite, disposed in layers, characterize the $\mathrm{C}$-Isotope stage 1 , whereas variable amounts of graphite, disposed in layers and some times disseminated, are commonly found associated to $\mathrm{C}$-isotope stage 2. Finally, variable amounts of 

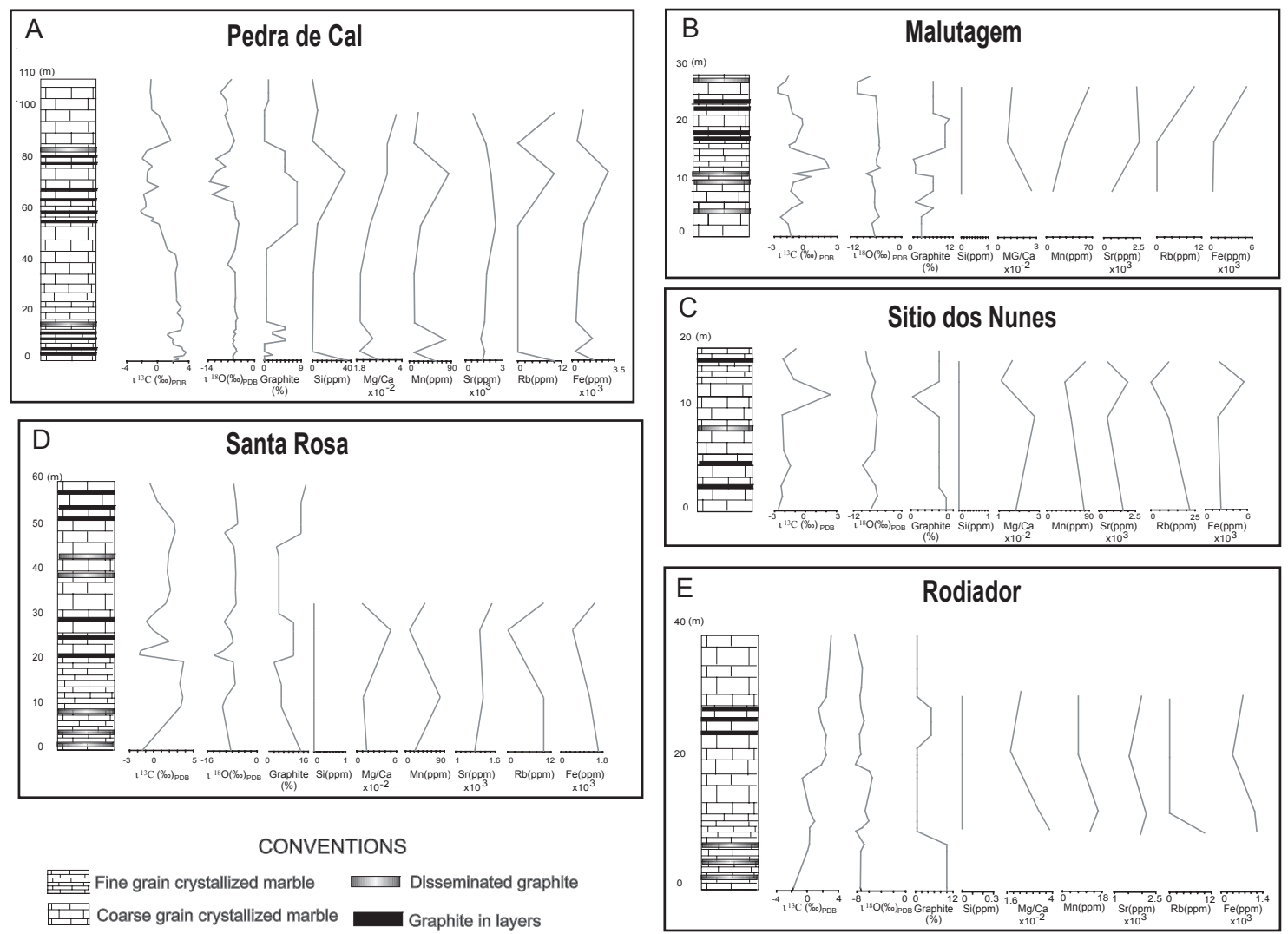

Fig. 5 - C- and O- isotope chemostratigraphic pathways for the studied marble successions. Note the inverse relationship between the $\delta^{13} \mathrm{C}$ stratigraphic trends and variations in the graphite content. Elemental stratigraphic variations are also included.

graphite, although less pronounced than those observed in C-isotope stage 2, are found in most of cases disposed in layers in the stratigraphic interval corresponding to the $\mathrm{C}$-isotope stage 3 .

\section{SR-ISOTOPE STRATIGRAPHY}

A composite ${ }^{87} \mathrm{Sr} /{ }^{86} \mathrm{Sr}$ curve was constructed based on the well-constrained C-Isotope composite chemostratigraphic curve (Fig. 6). ${ }^{87} \mathrm{Sr} /{ }^{86} \mathrm{Sr}$ values averaging 0.706 where found in the lower portion of the sequence, characterizing the $\mathrm{C}$-isotope stage 1 . Values increase to $\sim 0.707$ and then fall again, up section, to values near 0.706 in the stratigraphic interval corresponding to the $\mathrm{C}$-isotope stage 2 , to finally shift to values $\sim 0.707$. In the uppermost portion of the sequence and coinciding with the $\mathrm{C}$ isotope stage 3 , values decrease to $\sim 0.706$, remain- ing constant through the upper-most portion of the composite chemostratigraphic curve.

\section{DISCUSSION}

\section{Regional Implications of the São Caetano COMPLEX C AND SR ISOTOPE COMPOSITION}

C- and Sr-isotope composition of carbonate sequences has been successfully used to correlate marine carbonate sequences worldwide and to indirectly constrain their depositional age (Kah et al. 1999, Bartley et al. 2001, among others). The effectiveness of this approach has not only been demonstrated for limestone sequences, but also on marble successions, in which the lack of fossils and other geochronologic indicators make age determinations rather difficult (Kaufman et al. 1991).

The $\delta^{13} \mathrm{C}$ secular variation pathways encoun- 


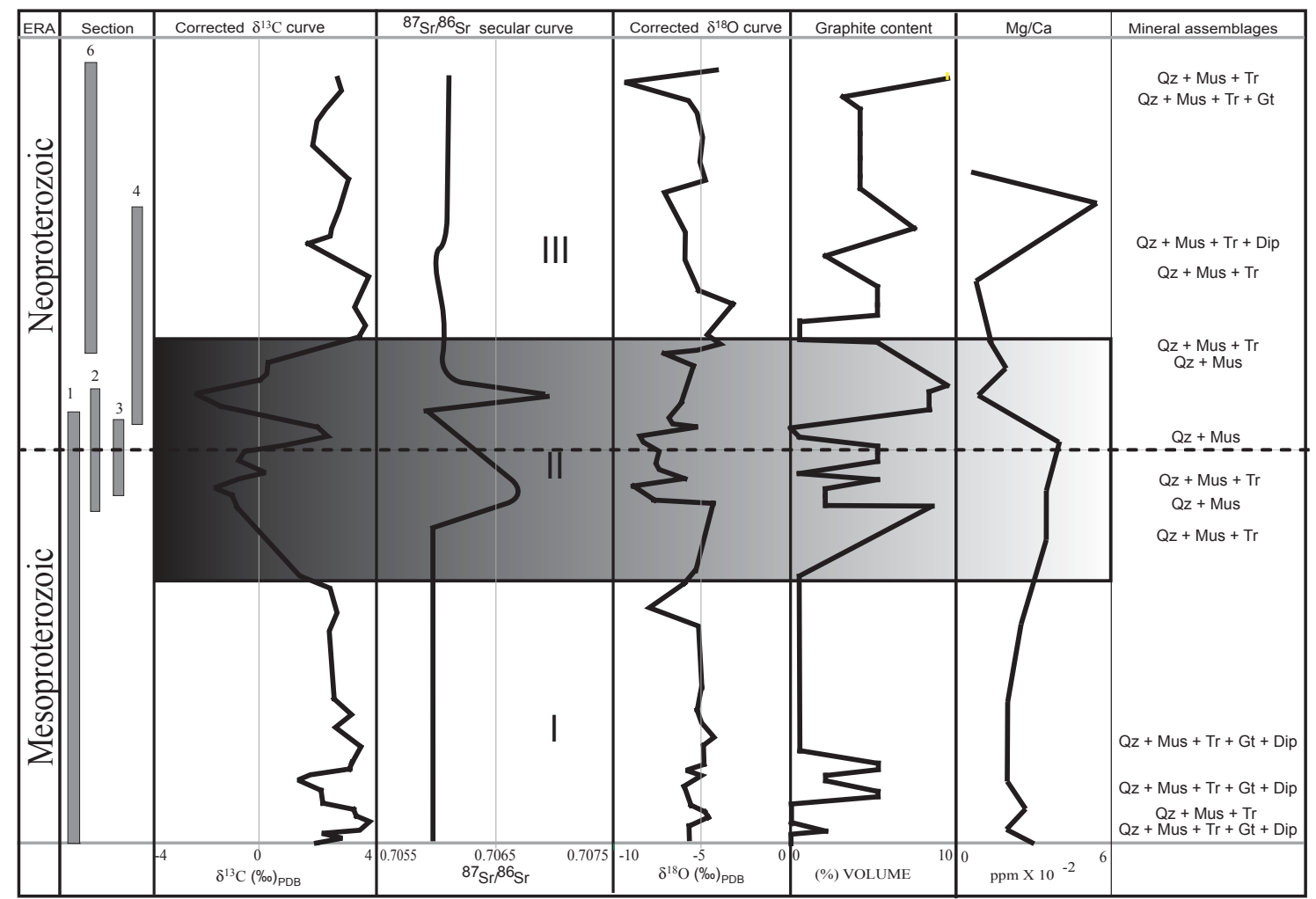

Fig. 6 - C-, Sr- and O- isotope composed chemostratigraphic curve of the São Caetano marble successions. Roman numbers represent the $\mathrm{C}$-isotope stages 1,2 and 3 identified in this study. Perturbations in the ${ }^{87} \mathrm{Sr} /{ }^{86} \mathrm{Sr}$ secular variation curve are coincident with perturbations in the $\delta^{13} \mathrm{C}$ secular variation curve. No correlation is observed between changes in silicate mineral assemblages and changes in the isotope curves. Special attention is drawn on the opposite behavior between the graphite content and the $\delta^{13} \mathrm{C}$ secular variation curves. In the left most column numbers represent the studied stratigraphic sections: 1. Pedra de Cal, 2. Malutagem, 3. Sitio dos Nunes, 4. Rodiador, 5. Santa Rosa. In the right column quartz (Qz), muscovite (Mus), tremolite (Tr), diopside (Dip), garnet (Gt).

tered in the SCC marbles seem to closely match with those encountered in Meso-Neoproterozoic carbonate sections in Canada and Siberia (Fig. 7) (Knoll et al. 1995, Kah et al. 1999, Bartley et al. 2001). For instance, carbonate sequences from Siberia (Bartley et al. 2001) and Canada (Kah et al. 1999) present mostly positive $\delta^{13} \mathrm{C}$ values ( $+4 \%$ PDB $)$, which are interrupted by a large depletion towards negative values $(-2.7 \%$ PDB $)$; the latter separated by a large positive excursion of near $\sim 5 \%$ PDB (from -2.4 to $\sim+2.4 \%$ PDB ) (Fig. 7). According to Bartley et al. (2001) such a positive excursion $(-2.4$ to $+2.4 \%$ PDB $)$ marks the Meso-Neoproterozoic passage $(\sim 1 \mathrm{Ga})$. On the other hand, the age of the positive isotopic plateau (3-4\% PDB) preceding the above mentioned positive excursion was constrained based on a $\mathrm{Pb}-\mathrm{Pb}$ isochron for carbonates from Siberia, which yield an age of $1.03 \mathrm{Ga}$ (Ovchinnikova et al. 1995). Additional age data, based on isotopic analyses of glauconite-illite series minerals, provided an age of near $1.17 \mathrm{Ga}$ for the stratigraphic levels presenting this isotopic plateau in the Kerpyl Group, Siberia (Bartley et al. 2001).

Bartley et al. (2001) reported ${ }^{87} \mathrm{Sr} /{ }^{86} \mathrm{Sr}$ data averaging 0.706 from some middle Riphean successions in Siberia (Turukhansk Uplift, Sukhaya Tunguska Formation) and values between 0.706 and 0.7065 from their late Riphean counterparts. These 


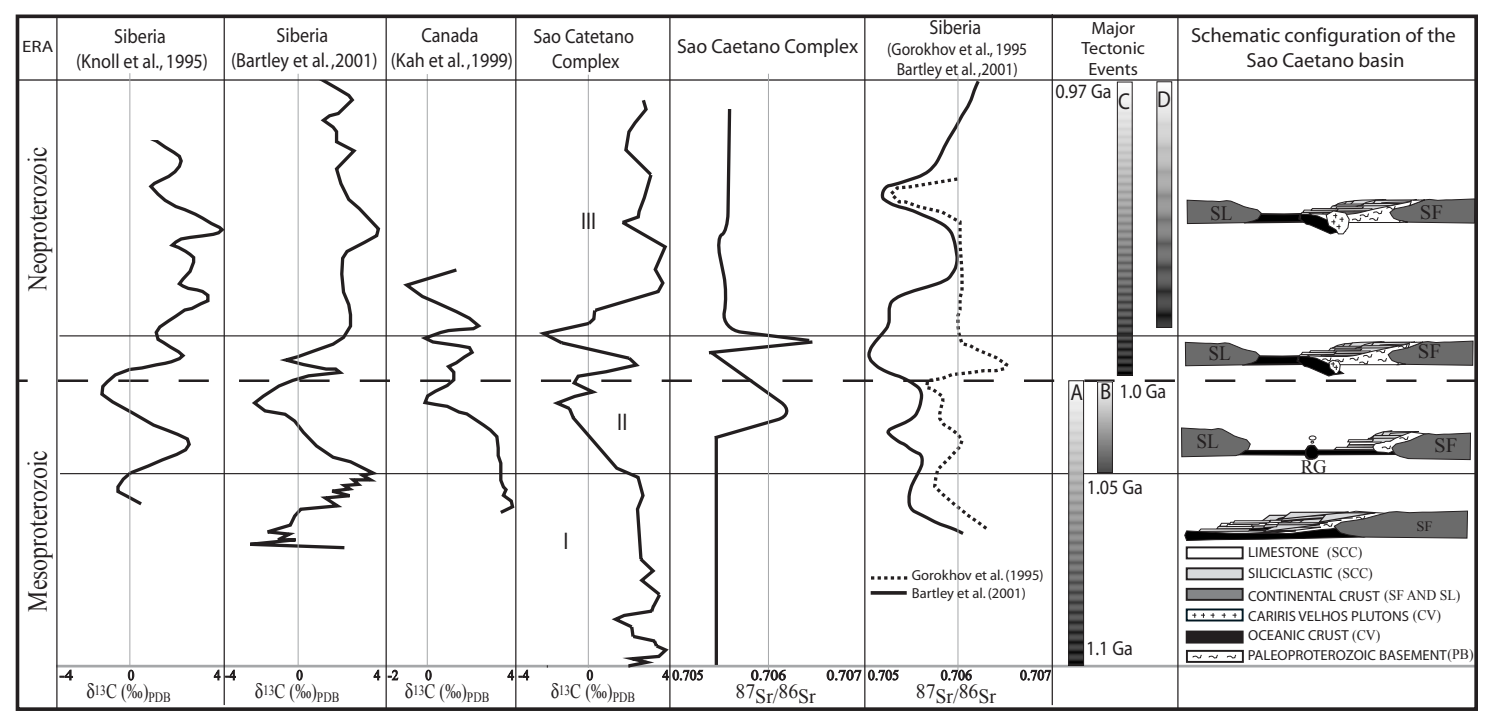

Fig. 7 - Chemostratigraphic C- and Sr- trends from different carbonate sequences worldwide representing the original composition of the Meso-Neoproterozoic seawater. Note the similarity between the chemostratigraphic pathways from SCC marbles and those from unmetamorphosed sequences in Siberia and Canada. Roman numbers represent C-isotope stages 1, 2 and 3. Strong perturbations in C- and Sr- chemostratigraphic record seem to coincide with major tectonic events. (A) Offset of the Greenville orogeny, (B) Late Mesoproterozoic Rifting, (C) Cariris Velhos Orogeny, (D) Rodinia agglutination. A schematic configuration of the SCC basin is also shown. (SF) São Francisco Craton, (SL) São Luis Craton, (RG) Riacho-Gravata Complex.

data supplemented the data obtained by Kah et al. (2001), who reported values between 0.7052 and 0.706 from Mesoproterozoic carbonates of the Bylot Supergroup in Canada, as well as from gypsum successions of the Society Cliffs Formation in Canada. Nevertheless, Gorokhov et al. (1995) reported increasing ${ }^{87} \mathrm{Sr} /{ }^{86} \mathrm{Sr}$ ratios, from 0.706 to 0.7065 , obtained in middle-late Riphean (MesoNeoproterozoic transition) successions in Siberia.

The ${ }^{87} \mathrm{Sr} /{ }^{86} \mathrm{Sr}$ values reported in the literature for the Mesoproterozoic-Neoproterozoic transition are quite similar to those for the SCC marble sequences (Fig. 7). Although Bartley et al. (2001) proposed that ${ }^{87} \mathrm{Sr} /{ }^{86} \mathrm{Sr}$ values around 0.705 characterize the middle-upper Riphean transition, values around 0.707 found for SCC marbles are quite similar to those reported by Gorokhov et al. (1995) for the same time span. However, similar values from the Turukhansk Uplift (Siberia) were considered by Bartley et al. (2001) as representing postdepositional alteration.
On the basis of the similarities between the Cand $\mathrm{Sr}$-isotope chemostraigraphic pathways encountered in the above-mentioned carbonate sequences and those herein reported from the SCC, a sedimentation spanning from 1.1 to $\sim 0.97 \mathrm{Ga}$ is proposed. This suggests that oceanic conditions likely dominated part of the Transversal Domain of the Borborema Structural Province during the MesoNeoproterozoic boundary and consequently, that the Transversal Domain remained as an open oceanic basin during that time span. This implies that the proposed landmasses collisional processes associated to the agglutination of Rodinia supercontinent (Brito Neves et al. 2000), would have not taken place before $0.97 \mathrm{Ga}$ in the Transversal Domain. The same conclusion has been recently reached by Kröner and Cordani (2003) who envisaged the possibility of a small and narrow oceanic basin in the Transversal Domain, during a period of continental expansion and rifting around $1.0 \mathrm{Ga}$. 
Global Implications of the LATE

Mesoproterozoic- Early Neoproterozoic C

AND SR-ISOTOPE RECORD

Since changes in the C- and Sr-isotope composition of seawater have been ascribed to miscellaneous processes, a brief discussion about the factors that can eventually affect such an isotopic composition will be addressed before discussing the late Meso- early Neoproterozoic record.

Oscillatory $\delta^{13} \mathrm{C}$ pathways encountered in carbonate sequences worldwide have been attributed, in the long term, to periods of high tectonic activity during which inputs and outputs of the available $\mathrm{C}_{\text {org }}$ resulted in changes in the $\mathrm{C}$-isotope composition of seawater respectively (Derry et al. 1992, Lindsay and Brasier 2002, Bekker et al. 2003). For instance, enriched $\delta^{13} \mathrm{C}$ values have been attributed to periods of high tectonic activity during which enhanced $\mathrm{C}_{\text {org }}$ burial causes high levels of oxygenation levels in ocean and atmosphere, as well as high biologic diversification events (Des Marais 1997). These values are also expected during periods of high $\mathrm{C}_{\text {org }}$ sequestration during widespread subduction of $\mathrm{C}_{\text {org }}$-rich sedimentary slabs and during widespread oceanic closure (Lindsay and Brasier 2000, 2002, Bekker et al. 2003). Alternatively, it has also been proposed that short lasting phenomena such as upwelling, relative sea level changes, ocean water stratiphication, among other, can also generate fluctuating, environment dependant $\delta^{13} \mathrm{C}$ pathways in the sedimentary record as observed in Phanerozoic sedimentary succession (Mitchell et al. 1996, Scholle and Arthur 1980). Oppositely, low $\delta^{13} \mathrm{C}$ values are associated to periods of stable tectonics, in which low $\mathrm{C}_{\text {org }}$ burial contribute to the oxidation and incorporation of the available crustal ${ }^{12} \mathrm{C}$-rich organic material being incorporated into the ocean system (Des Marais 1994, Kah et al. 1999, Bartley et al. 2001). Depleted $\delta^{13} \mathrm{C}$ values can be also expected during periods of oceanic rifting and spreading, as well as during the occurrence of mantle superplumes, in which ${ }^{13} \mathrm{C}$-depleted volcanic $\mathrm{CO}_{2}$ is released into the ocean water (Lindsay and Brasier
2000, 2002).

On the other hand, the $\mathrm{Sr}$ isotopic composition of seawater have been associated to diverse phenomena such as mid-oceanic rifting (outgassing), alteration of seafloor basalt and continental crust weathering and associated $\mathrm{Sr}$ isotope incorporation into the ocean via riverine discharge. Under this perspective, general agreement exists in that low ${ }^{87} \mathrm{Sr} /{ }^{86} \mathrm{Sr}$ values have been associated to mid oceanic volcanic activity (outgassing) and to alteration of seafloor basalt, whereas high ${ }^{87} \mathrm{Sr} /{ }^{86} \mathrm{Sr}$ values have been associated mostly to continental weathering (Veizer et al. 1997).

The Mesoproterozoic seems to have been a crucial period of the evolution of Earth, during which strong and global tectonic events (e.g. Greenville, agglutination of supercontinent Rodinia, widespread rifting) (Hoffman 1999), large $\mathrm{C}_{\text {org }}$ sequestration through burial and concomitant oceanic redox conditions (Des Marais et al. 1992, Canfield 1998), carbonate saturation of ocean water (Kah et al. 2001, Bartley and Kah 2003) and biochemical ecstasy (Knoll 1992) seem to have fashioned the Cisotope composition of seawater.

Some authors (e.g. Buick et al. 1995, Knoll et al. 1995, Brasier and Lindsay 1998) have proposed that tectonic stability, biochemical ecstasy (appearance and diversification of Eukaryotes) and oceanic geochemical quiescence derived from large oceanatmosphere equilibrium generated an almost invariant C-isotope composition of the Mesoproterozoic seawater. Other authors, in contrast, have invoked the occurrence of enhanced $\mathrm{C}_{\text {org }}$ matter burial, occurring during the agglutination of Rodinia, to explain secular variations in the middle Meso-late Neoproterozoic $\delta^{13} \mathrm{C}$ record (Kah et al. 1999, Bartley et al. 2001). Such an enhancement in the $\mathrm{C}_{\text {org }}$ burial would have prevented ${ }^{12} \mathrm{C}$-rich material to oxidize and thus, the concomitant incorporation of the available ${ }^{12} \mathrm{C}$ into the ocean water, generating high ocean water oxygenation levels that led to an increase in life diversification, which in turn, generated a general $\delta^{13} \mathrm{C}$ increase in the seawater due to high ${ }^{12} \mathrm{C}$ biological consumption. 
Alternatively, Bartley and Kah (2003) and Frank et al. $(1997,2003)$ proposed that these slightly fluctuating C-isotope pathways should have been related to large changes in the biochemical cycles and in the mass balance between the inorganic $\left(\mathrm{C}_{\text {carb }}\right)$ and organic $\left(\mathrm{C}_{\mathrm{org}}\right)$ carbon reservoirs; which would have resulted in ${ }^{13} \mathrm{C}$ depleted-anoxic deep ocean and ${ }^{13} \mathrm{C}$-rich shallow marine waters.

On the other hand, variation in the Mesoproterozoic Sr-isotope chemostratigraphic record has been somehow more understood than the Cisotope one, despite the scarcity of data. It has been proposed, for example, that such an increase in the seawater $\mathrm{Sr}$-isotope composition (from $\sim 0.704$ to $\sim 0.707$ ) occurring between the early Mesoproterozoic and early Neoproterozoic seems to have occurred as a result of changes in the global tectonic activity (Veizer et al. 1992, Hall and Veizer 1996, Gorokhov et al. 1995, Bartley et al. 2001). For instance, the lowest values observed during the early Mesoproterozoic have been associated to widespread early Riphean rifting activity (Veizer et al. 1992) whereas the high radiogenic values obtained for the late Mesoproterozoic- early Neoproterozoic time span have been attributed to enhanced continental Sr inputs during the onset of the agglutination of Rodinia supercontinent and associate orogenic events (Bartley et al. 2001, Kah et al. 2001).

Based on the published C- and Sr-isotope database, on the SCC chemostratigraphic record and on other lines of evidence, it seems that the late Mesoproterozoic- early Neoproterozoic (1.1$0.97 \mathrm{Ga}$ ) C- and Sr-isotope composition of seawater would have been primarily controlled by tectonic activity (Fig. 7). For instance, the positive $\delta^{13} \mathrm{C}$ values $(3-4 \%$ ) found in middle-middle Riphean successions worldwide (C-isotope stage 1) (Kah et al. 1999, Bartley et al. 2001) would have been controlled by a combination of global $\mathrm{C}_{\text {org }}$ burial and sequestration through subduction during the peak of the Greenville orogeny ( $\sim 1.1 \mathrm{Ga}$.), when widespread orogenic belts and subduction zones would have extensively developed (McLelland et al. 1996). Such an orogenic peak would have also led to moderate ${ }^{87} \mathrm{Sr} /{ }^{86} \mathrm{Sr}$ values (0.7060) (Gorokhov et al. 1995 ) in the contemporaneous seawater as a result of large amounts of juvenile material, generated during the lower Riphean rifting event, being incorporated into the continental margins of the forming Rodinia supercontinent (Bartley et al. 2001).

In contrast, during the upper middle- late Riphean time, the occurrence of widespread rifting occurring in the São Francisco Craton (D'AgrellaFilho et al. 1990) and in between different continental landmasses $(\sim 1.05 \mathrm{Ga}$ ) (Kröner and Cordani 2003), including the Transversal Domain in the Borborema Province (e.g. Riacho Gravata Complex; Brito Neves et al. unpublished data) as well as the apparition of several continental margin magmatic arcs (e.g. Cariris Velhos, Sri Lanka) (Kröner et al. 2003, Kröner and Cordani 2003, Brito Neves et al. unpublished data) would have considerably affected the C- and Sr- seawater isotope composition (Fig. 7). The former tectonic event would have generated the decreasing $\delta^{13} \mathrm{C}$ trends (from +2 to $-2 \%$ ) observed in unmetamorphosed sequences (Knoll et al. 1995, Kah et al. 1999, Bartley et al. 2001) and those observed in metamorphosed ones (lowermost portion of the $\mathrm{C}$-isotope stage 2), as a consequence of the large addition of ${ }^{13} \mathrm{C}$ depleted $\mathrm{CO}_{2}$ during oceanic rifting. Additionally, this phenomenon would explain the low ${ }^{87} \mathrm{Sr} /{ }^{86} \mathrm{Sr}$ values (0.705-0.706) encountered for the same time span as a result of addition of large volumes of oceanic (juvenile) crust (Fig. 7) (Gorokhov et al. 1995, Bartley et al. 2001).

The occurrence of the above mentioned continental margin magmatic arcs $(1.0 \mathrm{Ga})$, in contrast, would have caused the observed $\delta^{13} \mathrm{C}$ positive excursion (Knoll et al. 1995, Kah et al. 1999, Bartley et al. 2001) during the middle interval of the $\mathrm{C}$-isotope stage 2 . This short lasting and sharply positive excursion would have been the result of the extensive sequestration of $\mathrm{C}_{\mathrm{org}}$-rich materials, through burial and subduction, during a period of global sea level rise (Knoll et al. 1995, Li et al. 2003); which would have caused the $\mathrm{C}$-isotope composition of seawater to fluctuate. In other words, the increasing ${ }^{13} \mathrm{C}$ 
enrichment, which resulted from $\mathrm{C}_{\text {org }}$ sequestration, would have rapidly shifted back towards the negative values observed below such a positive excursion as a result of a sea level rise. Finally, this continental margin magmatic arc and related mountain building would have invigorated the exumation of continental crust material, causing a slight increase in the ${ }^{87} \mathrm{Sr} /{ }^{86} \mathrm{Sr}$ values to 0.7070 as well (Fig. 7).

The negative $\delta^{13} \mathrm{C}$ values $(\sim-2 \%$ ) that characterize the middle-upper portion of the $\mathrm{C}$ isotope stage 2 , which then shift back towards positive values $(\sim+3 \%$ ) in its upper most part and finally reach $\sim+3.7 \%$ in the $\mathrm{C}$-isotope stage 3 characterize the early-middle Upper Riphean time and are interpreted here as the conjugation of the two following factors: (a) the continuing sequestration through subduction of ${ }^{12} \mathrm{C}$-rich continental derived material, associated to the onset of the above mentioned continental margin magmatic arc (1.0 and 0.97 Ga.) (Kröner et al. 2003, Kröner and Cordani 2003), and (b) enhanced global sea level fall (Fig. 7).

From this panorama, it can be concluded that the $\mathrm{C}$ - and Sr- secular variation curves for the SCC and, in general, the late Mezoproterozoic- early Neoproterozoic C and Sr-isotope curve, seem to represent variations in the original geochemistry of seawater, which in turn would have been controlled by worldwide major tectonic events during its deposition (e.g. peak of the Greenville orogeny $(1.1 \mathrm{Ga})$, oceanic rifting activity $(1.05 \mathrm{Ga})$ and continental magmatic arc formation (= Cariris Velhos event; 1.0-0.85 Ga). The same kind of mechanisms were evoked by Lindsay and Brasier (2002) to explain perturbations in the $\mathrm{C}$-isotope composition of seawater during the Paleoproterozoic, period during which tectonic activity produced noticeable shifts in the seawater geochemistry after a period of apparent geochemical quiescence. Hence, major tectonic episodes must be regarded as primordial factors capable to control and modify the global C-cycle and thus the C- and Sr-isotope composition of seawater through time.

\section{ACKNOWLEDGMENTS}

We thank Gilsa M. Santana and Vilma S. Bezerra, for the assistance with $\mathrm{C}$ - and $\mathrm{O}$-isotope analyses and also for sample preparation for Sr-isotope analysis. We also thank Simone Gioia for assistance with Srisotope analyses at the University of Brasilia. J.C. Silva wishes to express his gratitude to COLFUTURO for providing a full-tuition scholarship. This is the NEG-LABISE contribution N. 230.

\section{RESUMO}

Valores de isótopos de $\mathrm{C}$ e ${ }^{87} \mathrm{Sr} /{ }^{86} \mathrm{Sr}$ de cinco seqüências de carbonatos do Complexo São Caetano, nordeste do Brasil; foram usados para estimar a sua idade de deposição e relacionar variações da composição isotópica na água do mar com eventos tectônicos globais. Três estágios de variação de isótopos de carbono foram identificados de base para o topo numa seção quimioestratigráfica composta: (1) estágio em que $\delta^{13} \mathrm{C}$ varia de +2 $\mathrm{a}+3.7 \%$ PDB (media $3 \%$ PDB), (2) estágio no qual $\delta^{13} \mathrm{C}$ varia consideravelmente (de $-2 \mathrm{a}+3 \%$ PDB) e (3) estágio apresentando valores constantes de cerca de $+3.7 \%$ PDB. Valores de ${ }^{87} \mathrm{Sr} /{ }^{86} \mathrm{Sr} \sim 0.70600$ caracterizam o estágio isotópico 1 , tornando-se mais variáveis no estágio isotópico 2 (entre $\sim 0.70600 \mathrm{e} \sim 0.70700$ ). Finalmente, valores em torno de 0.70600 caracterizam o estágio isotópico 3.

A quimioestratigrafía de $\mathrm{C}$ e $\mathrm{Sr}$ permite concluir que: (a) as curvas de variação seculares dos carbonatos do Complexo São Caetano registram flutuações primárias na composição isotópica de $\mathrm{C}$ e $\mathrm{Sr}$ da água do mar durante a passagem Meso-Neoproterozóico na Província Borborema; (b) o ciclo orogênico Cariris velhos/Greenville, a ocorrência de rifteamento e formação de arcos magmáticos continentais, e a formação do supercontinente Rodinia, controlaram a composição isotópica de $\mathrm{C}$ e $\mathrm{Sr}$ da água do mar durante os estágios isotópicos 1, 2, 3 .

Palavras-chave: isótopo de carbono, Meso-Neoproterozóicos, quimioestratigrafia, Província Borborema, nordeste brasileiro.

\section{REFERENCES}

Azmy K, Veizer J, Misi A, Oliveira T, Sanches A AND Dardenne M. 2001. Dolomitization and isotope stratigraphy of the Vazante Formation, São Francisco Basin, Brazil. Precamb Res 112: 303-329. 
Banner J AND Hanson G. 1990. Calculation of simultaneous isotope and trace element variations during water-rock interaction with application to carbonate diagenesis. Geochim Cosmochim Acta 54: 3123-3138.

Bartley J and Kah L. 2003. Marine DIC, $\mathrm{C}_{\text {org }}-\mathrm{C}_{\text {carb }}$ coupling and the evolution of the Proterozoic carbon Cycle. Geology 2: 129-132.

Bartley J, Knoll A, Grotzinger J and Sergeev V. 2000. Lithification and fabric genesis in precipitated stromatolites and associated peritidal carbonates, Mesoproterozoic Billyakh Group, Siberia. In: Grotzinger J And James N. (Ed). Carbonate sedimentation and diagenesis in the evolving Precambrian world. SEPM Special Publication 67, Tulsa, OK, p. 59-74.

Bartley J, Semikhatov M, Kaufman A, Knoll A, Pope M and Jacobsen S. 2001. Global events across the Meso-Neoproterozoic boundary: $\mathrm{C}$ and $\mathrm{Sr}$ Isotopic evidence from Siberia. Precamb Res 111: 165-202.

Bekker A, Karhu J, Eriksson K and Kaufman A. 2003. Chemostratigraphy of the Paleoproterozoic carbonate successions of the Wyoming Craton: Tectonic forcing of biochemical change? Precamb Res 120: 279-325.

Brand U and Veizer J. 1980a. Chemical diagenesis of a multicomponent carbonate system-1: Trace elements. J Sed Petrol 50: 1219-1236.

Brand U And Veizer J. 1980b. Chemical diagenesis of a multicomponent carbonate system-2: Stable Isotopes. J Sed Petrol 51: 987-997.

Brasier M and Lindsay J. 1998. A billion years of environmental stability and the emergence of Eukaryotes: New data from Northern Australia. Geology 26: $555-558$.

Brito Neves B, Santos E and Van Schmus W. 2000. In: Cordani U ET AL. (Ed). Tectonic history of the Borborema Province, Northeastern Brazil. Tectonic Evolution of South America. $31^{\text {st }}$ IGC. Rio de Janeiro, Brazil, p. 151-193.

Buick R, Des Marais D and Knoll A. 1995. Stable isotope composition of carbonates from the Mesoproterozoic Bangemall Group, Northwestern Australia. Chem Geol 123: 153-171.
Canfield D. 1998. A new model for Proterozoic ocean chemistry. Nature 396: 450-453.

Chacko T, Mayeda T, Clayton R and Goldsmith J. 1991. Oxygen and carbon isotope fractionation between $\mathrm{CO}_{2}$ and calcite. Geochim Cosmochim Acta 55: 2867-2882.

Craig H. 1957. Isotope standard for carbon and oxygen and correction factors for mass spectrometry analysis of carbon dioxide. Geochim Cosmochim Acta 12: 133-149.

D’Agrella-Filho M, Pacca I, Renne P, Onstott T and Teixeira W. 1990. Paleomagnetism of the middle Proterozoic (1.01-1.08 Ga) mafic dikes in southern Bahia State. São Francisco Craton, Brazil. Earth Planet Sci Lett 10: 332-348.

Derry L, Kaufman J and Jacobsen S. 1992. Sedimentary cycling and environmental change in late Proterozoic: Evidence from stable and radiogenic isotopes. Geochim Cosmochim Acta 56: 1317-1329.

Des Marais D. 1994. Tectonic control of the crustal organic carbon reservoir during the Precambrian. Chem Geol 114: 303-314.

Des Marais D. 1997. Isotopic evolution of the biochemical carbon cycle during the Proterozoic Eon. Org Geochem 27: 185-193.

Des Marais D, Strauss H, Summons R and Hayes J. 1992. Carbon isotope evidence for the step-wise oxidation of the Proterozoic environment. Nature 359: 605-609.

Dunn S And Valley J. 1992. Calcite-graphite isotope thermometry: a test for polymetamorphism in marble, Tudor gabbro aureole, Ontario, Canada. J Metamorphic Geol 10: 487-501.

Ferreira V, Sial A and Jardim de Sá E. 1998. Geochemical and isotopic signatures of the Proterozoic granitoids in the terranes of the Borborema structural province, northeastern Brazil. J S Am Earth Sci 11: 439-455.

Frank T, Lyons T and Lohmann K. 1997. Isotopic evidence for the paleoenvironmental evolution of the Mesoproterozoic Helena Formation, Belt Supergroup, Montana. Geochim Cosmochim Acta 61: 5023-5041.

Frank T, KAH L AND Lyons T. 2003. Changes in organic matter production and accumulation as a mechanism 
for isotopic evolution in the Mesoproterozoic ocean. Geol Mag 140: 397-420.

Gomes H. 1999. Programa levantamentos geológicos básicos do Brasil. Folha SB. 24-Z-C. Serra Talhada. Estado de Pernambuco, Paraíba e Ceará. Serviço geológico do Brasil (CPRM) Ministério de Minas e Energia. Brasília, p. 57.

Gorokhov I, Semikhatov M, Baskakov A, Kutyavin E, Melnikov N, Sochava A and Turchenko T. 1995. Sr isotopic composition in Riphean, Vendian, and Lower Cambrian carbonates from Siberia. Stratigr Geol Correl 3: 1-28.

Hall S And Veizer J. 1996. Geochemistry of Precambrian carbonates VII: Belt Supergroup, Montana and Idaho, USA. Geochim Cosmochim Acta 60: 667-677.

Hoffman P. 1999. The break-up of Rodinia, birth of Gondwana, true polar wander and the snowball Earth. J African Earth Sci 28: 17-33.

Hoffman P And Schrag D. 2002. The snowball Earth hypothesis: Testing the limits of global change. Terra Nova 14: 129-155.

Jacobsen S And Kaufman A. 1999. The Sr, C and O isotopic evolution of the Neoproterozoic seawater. Chem Geol 161: 37-57.

Kah L, Sherman A, Narbonne G, Kaufman A, Knoll A AND JAMES N. 1999. Isotope stratigraphy of the Mesoproterozoic Bylot supergroup, Northern Baffin Island: Implication for regional lithostratigraphic correlation. Can J Earth Sci 36: 313-332.

Kah L, Lyons T and Chesley J. 2001. Geochemistry of a $1.2 \mathrm{Ga}$ carbonate-evaporite succession, northern Baffin and Bylot Island: Implications for Mesoproterozoic marine evolution. Precamb Res 111: 203-236.

Kaufman A And KnOll A. 1995. Neoproterozoic variations of the C-isotopic composition of seawater: stratigraphic and biochemical implications. Precamb Res 73: 27-49.

Kaufman A, Hayes J, Knoll A and Germs G. 1991. Isotopic compositions of carbonates and organic carbon from upper Proterozoic successions in Namibia: stratigraphic variation and the effects of diagenesis and metamorphism. Precamb Res 49: 301-327.

Kaufman A, Jacobsen S and Knoll A. 1993. The Vendian record of $\mathrm{Sr}$ - and $\mathrm{C}$ - isotopic variations in sea- water: Implications for tectonics and paleoclimate. Earth Plan Science Lett 120: 409-430.

Kitchen N and Valley J. 1995. Carbon isotope thermometry in marbles of the Adirondack Mountains, New York. J Metamorphic Geol 13: 577-594.

KNOLL A. 1992. The early evolution of Eukaryotes: a geological perspective. Science 256: 622-627.

Knoll A, Kaufman A and Semikhatov M. 1995. The carbon isotopic composition of Proterozoic carbonates: Riphean successions from northwestern Siberia (Andabar Massif, Turukhansk uplift). Am J Sci 295: 823-850.

Kröner A ANd Cordani U. 2003. African, Southern India and South American cratons were not part of the Rodinia supercontinent: evidence from field relationships and geochronology. Tectonophysics 375 : 325-352.

Kröner A, Kehelpannala K and Hegner E. 2003. Ca. 750-1100 Ma magmatic events and Greenvilleage deformation in Sri Lanka: relevance for Rodinia supercontinent formation and dispersal, and Gondwana amalgamation. J Asian Earth Sci 22: 279-300.

Li C, Peng P, Sheng G, Fu J and Yan Y. 2003. A molecular and isotopic geochemical study of Mesoto Neoproterozoic (1.73-0.85 Ga) sediments from the Jixian section, Yanshan Basin, North China. Precamb Res 125: 337-356.

Lindsay J AND Brasier M. 2000. A carbon isotope reference curve c.a. 1700-1775 Ma, McArthur and Mount Isa Basins, northern Australia. Precamb Res 99: 271-308.

Lindsay J AND Brasier M. 2002. Did global tectonics drive early biosphere evolution? Carbon isotope record from 2.6 to 1.9 Ga carbonates of western Australian basins. Precamb Res 114: 1-34.

Maheshwari A, Sial A, Sharma A, Hussain S and Chauhan N. 2002. Carbon isotope composition of Raialo carbonates and its equivalents, Delhi supergroup, India: implications for stratigraphic correlation. Gondwana Res 5: 554-556.

Mclelland J, Daly J and Mclelland J. 1996. The Greenville orogenic cycle (ca. 1350-1000 Ma); an Adirondack perspective. Tectonophysics 265: 1-28.

Melezhik V, Fallick A and Clark T. 1997. Two billion years-old isotopically heavy carbon: evidence from the Labrador Trough, Canada. Can J Earth Sci 34: 271-285. 
Mitchell S, Paul C and Gale A. 1996. Carbon isotopes and sequence stratigraphy. In: Howell J AND Aitken J. (Ed.). High resolution sequence stratigraphy: innovations and applications. Geol Soci Spec Publ 104: 11-24.

Ovchinnikova G, Semikhatov M, Gorokhov I, BelyATSKII B, VAsIlieva I AND LeVSKII L. 1995. U-Pb systematics of Pre-Cambrian carbonates: the Riphean Sukhaya Tunguska Formation in the Turukhansk Uplift, Siberia. Lithology Min Resour 30: 525-536.

Santos R, Alvarenga C, Dardenne M, Sial A and Ferreira V. 2000. Carbon and oxygen isotope profiles across Meso-Neoproterozoic limestones from central Brazil: Bambuí and Paranoá groups. Precamb Res 104: 107-122.

Satish-Kumar M, Wada H and Santosh M. 2002. Constraints on the application of carbon isotope thermometry in high to ultrahigh temperature metamorphic terranes. J Metamorphic Geol 20: 335-350.

Scholle P AND Arthur M. 1980. Carbon isotope fluctuations in cretaceous pelagic limestones: Potential stratigraphic and petroleum exploration tool. AAPG Bull 64: 67-87.

Shieh Y AND TAYlor H. 1969. Oxygen and carbon isotope studies of contact metamorphism of carbonate rocks. J Petrol 10: 307-331.
VALLEY J. 2001. Stable isotope thermometry at high temperatures. In: Valley J And Cole D. (Ed.) Stable isotope geochemistry. Reviews in Mineralogy and geochemistry 43. Min Soc Am, p. 365-414.

Valley J and O'Neil J. $1981 .{ }^{13} \mathrm{C} /{ }^{12} \mathrm{C}$ exchange between calcite and graphite a possible thermometer for Greenville marbles. Geochim Cosmochim Acta 45: 411-419.

Van Schmus W, Brito Neves B, Hackspacher P and BABINSKI M. 1995, U/Pb and Sm/Nd geochronologic studies of Eastern Borborema Province, Northeastern Brazil:Initial conclusions. J S Am Earth Sci 8: 267288.

Veizer J And Hoefs J. 1976. The nature of ${ }^{18} \mathrm{O} /{ }^{16} \mathrm{O}$ and ${ }^{13} \mathrm{C} /{ }^{12} \mathrm{C}$ secular trends in sedimentary carbonate rocks. Geochim Cosmochim Acta 40: 1387-1395.

Veizer J, Plumb K, Clayton R, Hinton R and GrotZINGER J. 1992. Geochemistry of Precambrian carbonates V: Late Paleoproterozoic (1.8 \pm 0.25$)$ seawater. Geochim Cosmochim Acta 56: 2487-2501.

Veizer J, Buhl D, Diener A, Ebneth S, Podlaha O, Bruckschen P, Jasper T, Korte C, SchaAf M, Ala D AND Azmy K. 1997. Strontium isotope stratigraphy: potential resolution and event correlation. Review paper. Paleogeogr Paleoclimatol Paleoecol 132: 65-77. 